\title{
U.S. VIRGIN ISLANDS \\ GROUND-WATER QUALITY
}

By Allen Zack, Teresita Rodriques-Alonso, and Angel Roman-Mas

U.S. Geological Survey Open-File Report 87-0756 
DEPARTMENT OF THE INTERIOR

DONALD PAUL HODEL, Secretary

\section{U.S. GEOLOGICAL SURVEY}

Dallas L. Peck, Director

For additional information:

Chief Hydrologist

U.S. Geological Survey

407 National Center

Reston, VA 22092
For sale by:

U.S. Geological Survey

Books and Open-File Reports Section Federal Center

Box 25425

Denver, Colorado 80225

Use of trade names in this report is for descriptive purposes only and does not constitute endorsement by the U.S. Geological Survey 


\section{FOREWORD}

This report contains summary information on ground-water quality in one of the $\mathbf{5 0}$ States, Puerto Rico, the Virgin Islands, or the Trust Territories of the Pacific Islands, Saipan, Guam, and American Samoa. The material is extracted from the manuscript of the 1986 National Water Summary, and with the exception of the illustrations, which will be reproduced in multi-color in the 1986 National Water Summary, the format and content of this report is identical to the State ground-water-quality descriptions to be published in the 1986 National Water Summary. Release of this information before formal publication in the 1986 National Water Summary permits the earliest access by the public. 


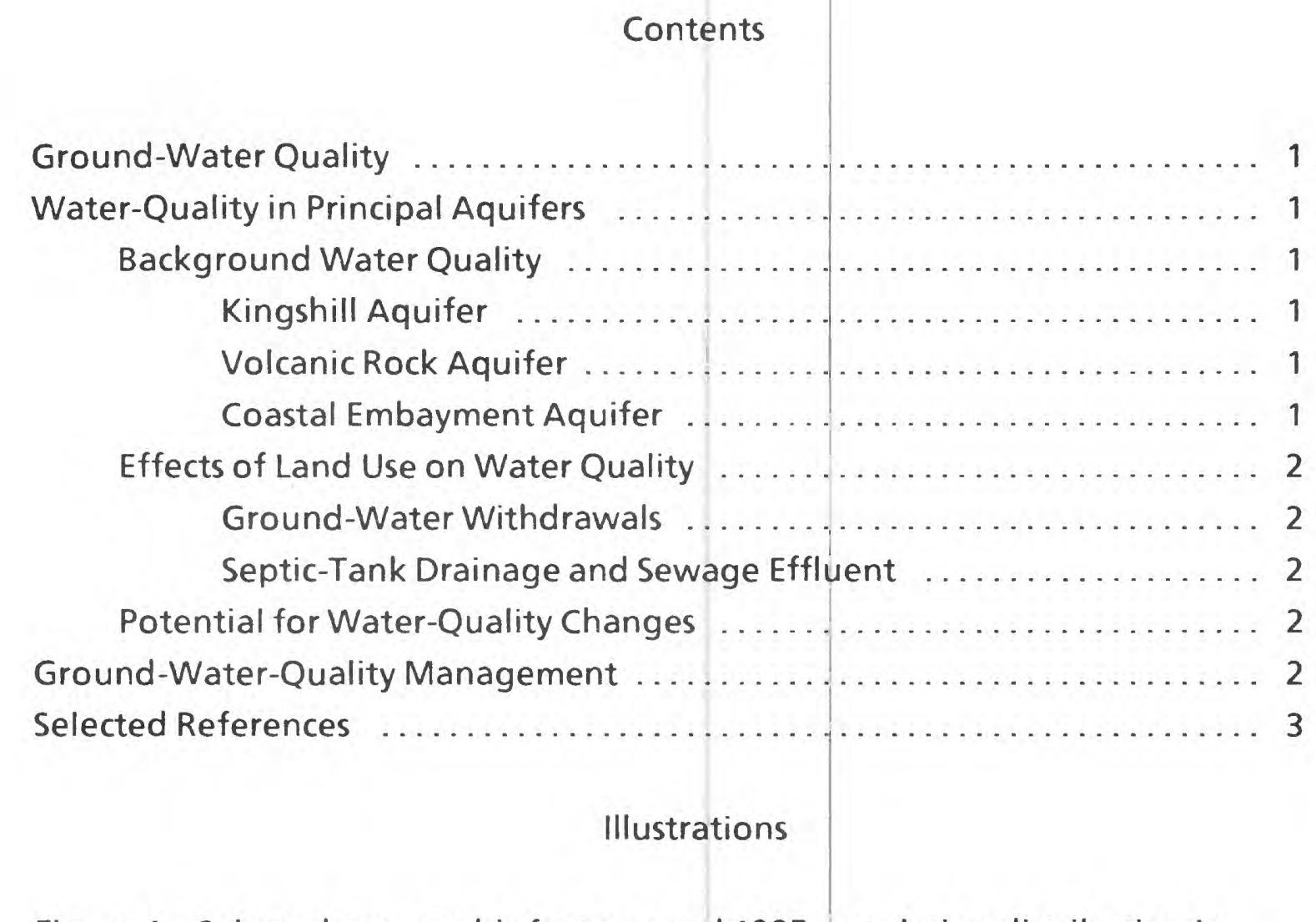

Figure 1.--Selected geographic features and 1985 population distribution in U.S. Virgin Islands.

Figure 2.--Principal aquifers and related water-quality data in

U.S. Virgin Islands.

Figure 3.--Selected waste sites and ground-water-quality information in U.S. Virgin Islands. 


\section{VIRGIN ISLANDS Ground-Water Quality}

The ground-water resources of the U.S. Virgin Islands are inadequate to meet the needs of the 100,000 inhabitants (fig. 1B) of the three major islands of St. Thomas, St. Croix, and St. John. Perennial streams are nonexistent; aquifers are limited in areal size and provide small yields to wells. Ground water, generally, does not meet the primary and secondary drinking-water standards established by the U.S. Environmental Protection Agency (1986a,b).

Ground water with a dissolved-solids concentration of less than $1,000 \mathrm{mg} / \mathrm{L}$ (milligrams per liter) is scarce throughout the U.S. Virgin Islands, and water with chloride concentrations as large as $500 \mathrm{mg} / \mathrm{L}$ is generally considered potable (Gomez-Gomez and Heisel, 1980, p. U14). In addition, large concentrations of nitrogen and widespread contamination by fecal coliform and fecal streptococci bacteria threaten the already limited ground-water resources (Garcia and Canoy, 1985).

The principal aquifers of the Islands supply about 17 percent of the Islands' water supply. Rooftop-rainfall catchments and desalination of seawater supply the remaining 83 percent. Groundwater withdrawals from aquifers in the U.S. Virgin Islands (fig. $2 A$ ) average $1.7 \mathrm{Mgal} / \mathrm{d}$ (million gallons per day) (Torres-Sierra and Dacosta, 1984; Torres-Sierra, 1986, p. 11); however, less than 10 percent of these withdrawals can be classified as freshwater (dissolved-solids concentration less than $1,000 \mathrm{mg} / \mathrm{L}$ ). The remaining saline ground-water withdrawals are either treated with reverse-osmosis desalination units or used for toilets, swimming pools, laundry, or wash water.

In spite of a steadily increasing demand for water, the geohydrology of the islands generally remains unstudied, and plans for further ground-water development are uncertain. Ground-waterquality data are scarce, and there are no active ground-water-quality monitoring networks on any of the three islands.

\section{WATER QUALITY IN PRINCIPAL AQUIFERS}

The U.S. Virgin Islands has three principal aquifers-the Kingshill aquifer, the volcanic rock aquifer, and the coastal embayment aquifer (fig. 2A). The Kingshill aquifer on St. Croix provides 67 percent of the total ground-water withdrawals in the U.S. Virgin Islands. The volcanic rock and coastal embayment aquifers, which occur on all three of the islands, represent 25 and 8 percent of the total ground-water withdrawals, respectively.

Ground-water quality is affected by precipitation which contains large concentrations of salt derived from sea-spray-laden air (Jordan and Cosner. 1973). The salt concentration in ground water is increased further by the rapid rate of evapotranspiration (U.S. Geological Survey, 1985, p. 409). Near coastal areas, saltwater occurs in all of the aquifers.

\section{BACKGROUND WATER QUALITY}

In 1984, the U.S. Geological Survey conducted a reconnaissance of selected wells throughout the U.S. Virgin Islands to determine the ground-water quality in the three principal aquifers. Water samples from wells located in the principal aquifers were analyzed to determine the physical, chemical and bacteriological characteristics. Selected water samples also were analyzed for priority pollutants, as designated by the U.S. Environmental Protection Agency (EPA).

A graphic summary of selected water-quality variables compiled by the U.S. Geological Survey is presented in figure $2 C$. The summary is based on dissolved-solids, hardness (as calcium car- bonate), nitrate (as nitrogen), chloride, and sulfate analyses of water samples collected from 1965 to 1985 from the principal aquifers in the U.S. Virgin Islands. Percentiles of these variables are compared to national standards that specify the maximum concentration or level of a contaminant in drinking-water supply as established by the U.S. Environmental Protection Agency $(1986 \mathrm{a}, \mathrm{b})$. The primary maximum contaminant level standards are health related and are legally enforceable. The secondary maximum contaminant level standards apply to esthetic qualities and are recommended guidelines. The primary drinking-water standards include a maximum concentration of $10 \mathrm{mg} / \mathrm{L}$ nitrate (as nitrogen), and the secondary drinking-water standards include maximum concentrations of $500 \mathrm{mg} / \mathrm{L}$ dissolved solids, $250 \mathrm{mg} / \mathrm{L}$ chloride, and 250 $\mathrm{mg} / \mathrm{L}$ sulfate.

\section{Kingshill Aquifer}

The Kingshill aquifer is the most productive and extensively developed aquifer in the U.S. Virgin Islands. The aquifer, which underlies approximately 25 square miles of central Saint Croix (U.S. Geological Survey, 1985, p. 410) is composed primarily of calcareous sediments. Along the coast and within the drainage basins, the aquifer is overlain with alluvium. The Kingshill aquifer is unconfined and contains a lens of relatively freshwater that overlies saline water (Robison, 1972).

Water from the Kingshill aquifer exceeds the secondary drinking-water standards for dissolved solids and chloride (fig. $2 \mathrm{C}$ ), with median concentrations of $1,440 \mathrm{mg} / \mathrm{L}$ and $560 \mathrm{mg} / \mathrm{L}$, respectively. A maximum chloride concentration of $2,200 \mathrm{mg} / \mathrm{L}$ has been reported for connate water within the Kingshill marl. The median nitrate (as nitrogen) concentration, $8.3 \mathrm{mg} / \mathrm{L}$, does not exceed the primary drinking-water standard; however, nitrate (as nitrogen) concentrations as large as $16 \mathrm{mg} / \mathrm{L}$ have been reported.

\section{Volcanic Rock Aquifer}

The volcanic rock aquifer, which is present on each of the islands (fig. $2 A$ ), is used almost exclusively for domestic supply, except on St. John, where the aquifer is used to supplement the public supply of desalinated water that is barged from Saint Thomas (U.S. Geological Survey, 1985, p. 410). The aquifer, which is composed of lava flows, fluvial tuffs, and breccias, is under confined to semiconfined conditions in fractures or in the weathered-rock mantle.

Although water from the volcanic rock aquifer is very hard (more than $180 \mathrm{mg} / \mathrm{L}$ as calcium carbonate), the water contains considerably smaller concentrations of dissolved solids, chloride, and sulfate than water from either the Kingshill or coastal embayment aquifers (fig. $2 C$ ). The median concentration of $2.7 \mathrm{mg} / \mathrm{L}$ nitrate (as nitrogen) is less than the primary drinking-water standard.

\section{Coastal Embayment Aquifer}

The coastal embayment aquifer, which is present on each of the islands (fig. $2 A$ ), consists of relatively thick deposits of unconsolidated sediments overlying weathered and fractured volcanic rocks (U.S. Geological Survey, 1985, p. 410). Although wells drilled in the unconsolidated sediments can yield more than 50 gallons per minute, the water is generally saline.

Median concentrations of dissolved solids and chloride are $2,150 \mathrm{mg} / \mathrm{L}$ and $261 \mathrm{mg} / \mathrm{L}$, respectively. The median concentra- 
tion of nitrate (as nitrogen) is $0.2 \mathrm{mg} / \mathrm{L}$. This is the smallest median nitrate concentration for the three aquifers.

Recent investigations by the U.S. Geological Survey in two of the coastal embayment aquifers on St. Thomas indicate that development of freshwater supplies may be possible (Fernando Gomez-Gomez, U.S. Geological Survey, written commun., 1986).

\section{EFFECTS OF LAND USE ON WATER QUALITY}

Ground-water quality has deteriorated in all three principal aquifers of the U.S. Virgin Islands, principally from excessive ground-water withdrawals, septic-tank drainage, and infiltration from stream courses conveying sewage-treatment-plant discharges or septic-tank overflows.

During the ground-water-quality reconnaissance in the islands in July 1984, water samples from several wells were analyzed to determine the presence of contamination by volatile organic chemicals and pesticides (Garcia and Canoy, 1985). In all the samples, concentrations of these constituents were less than minimum detection levels.

A report on 1983 ground-water conditions in the U.S. Virgin Islands (Geraghty and Miller, Inc., 1983) discusses degradation of ground-water quality, principally for the Kingshill aquifer on St. Croix and the volcanic rock aquifer on St. Thomas. The report indicates that many wells in the Kingshill aquifer contained an accumulation of lubricating oil from malfunctioning lubricating systems on well pumps. In several wells, as much as 8 feet of oil, floating on top of the water, was measured. The report also indicated that pentane was detected in water samples withdrawn from public water-supply wells in the Barren Spot well field in southern St. Croix (fig. $2 \mathrm{~A}$ ). Barium concentrations as large as $1.83 \mathrm{mg} / \mathrm{L}$ were also detected in some of the wells; the primary drinking-water standard for barium is $1 \mathrm{mg} / \mathrm{L}$. It is not known if the contaminating source of the barium and the pentane is the same.

Volatile organic chemicals were reported at a water-supply well at a Tutu housing project on St. Thomas (Geraghty and Miller, Inc., 1983). In addition, dichloroethylene, trichloroethylene, and tetrachloroethylene were detected by a private laboratory in three other wells on St. Thomas in concentrations of 12,10 , and $5.5 \mu \mathrm{g} / \mathrm{L}$ (micrograms per liter), respectively.

Ground-water contamination has not been detected at the one Resource Conservation and Recovery Act (RCRA) site on St. Croix (fig. 3), nor at any of the municipal landfills on the three islands (fig. 3). There are no Comprehensive Environmental Response, Compensation, and Liability Act of 1980 (CERCLA) sites on any of the three islands (U.S. Environmental Protection Agency, 1986c).

\section{Ground-Water Withdrawals}

Excessive ground-water withdrawals from the Kingshill aquifer on St. Croix have caused saltwater upconing and encroachment. Several investigations of the Kingskill aquifer (Cederstrom, 1950; Buros, 1976; Geraghty and Miller, Inc., 1983) have shown a correlation between pumping rate and chloride concentrations; however, such a correlation for wells in the coastal embayment aquifer or volcanic rock aquifer has not been documented. It is possible that the saltwater-yielding wells in the volcanic rock and coastal embayment aquifers are screened on the saltwater side of the freshwater-saltwater interface and, therefore, have not actually experienced saltwater encroachment.

\section{Septic-Tank Drainage and Sewage Effluent}

Wells throughout the U.S. Virgin Islands have been contaminated by septic-tank drain fields, leaky sewer lines, and sewage infiltration from sewage-treatment plant discharges to stream courses (fig. 3). Nitrate (as nitrogen) concentrations commonly exceed 5 $\mathrm{mg} / \mathrm{L}$, and fecal coliform and fecal streptococci bacteria have been detected in most wells (Garcia and Canoy, 1985). Fecal streptococci bacteria concentrations were as large as 5,800 colonies $/ 100 \mathrm{~mL}$ (milliliters) in a raw water from a well in the volcanic rock aquifer on St. Croix. In comparison, the Kingshill aquifer in St. Croix had the smallest concentrations of fecal coliform and fecal streptococci bacteria.

Contamination of wells and aquifers frequently occurs through the annular space between the well casing and the soil and rock materials of operating or abandoned wells. Substandard wellconstruction practices and deterioration of casings have apparently exposed some wells and the associated aquifers to contamination. In addition, the soil zone, usually less than 2 feet thick, is incapable of adequately filtering septic wastes and surface contamination and thus provides easy access to the aquifer through open joints or fractures.

\section{Potential for WATER-Quality Changes}

The continued use of aquifers as a water supply in the U.S. Virgin Islands is in jeopardy. The aquifers are being contaminated by sewage wastes, and saltwater encroachment is threatening the already limited, fresh ground-water resources.

Population increases have spurred housing developments in the headwaters of streams and in areas of ground-water recharge. In 1977, the Virgin Islands Planning Office estimated a population of 156,000 by the year 2000 (Peebles, and others, 1979, p. 17). Approximately one-half of the population of the U.S. Virgin Islands uses septic tanks, the effluent of which is often inadequately filtered because of a thin soil cover. In areas where soil and surface conditions are effective in filtering the sewage wastes, the density of septic systems often results in overloading the filtration capacity of the subsoil (Jordan and Cosner, 1973, p. 53). In the volcanic rock aquifer, open joints and fractures can promote widespread contamination of the aquifer.

Frequent breakdowns and overloads of sewage-treatment plants at many of the larger housing developments increase the chances of bacterial pollution in the aquifers. The treatment plants (and polishing ponds), which are intended to decrease the density of the septic-tank systems, are designed to eliminate most of the bacteria from the effluent. However, inadequate sewage treatment or plant overload generally is relieved by discharging effluent to dry stream channels. Discharging effluent into the stream channels, which are major ground-water-recharge areas, increases the potential for sewage effluent to contaminate the aquifers.

Saltwater contamination will also continue to threaten fresh ground-water supplies as long as wells continue to be improperly constructed. Continued overpumping of the aquifers will cause the freshwater-saltwater interface to move landward, thereby increasing the chances for further saltwater intrusion into the aquifers. Wells can be drilled in areas and at depths to take full advantage of the available freshwater, while not initiating saltwater migration. Controlled pumping, scavenger-wells, and barrier systems might be the most efficient freshwater-development strategy for the islands.

\section{GROUND-WATER-QUALITY MANAGEMENT}

The Department of Conservation and Cultural Affairs (DCCA) is charged with administering and enforcing most laws related to water resources and water pollution in the U.S. Virgin Islands. The DCCA develops standards for public water-supply systems; plans for emergency water supplies; controls well-construction permits; issues water-appropriation permits for all ground-water withdrawals greater than 500 gallons per day; and designs and constructs wastewater-treatment facilities. Also, the EPA has delegated to the DCCA the responsibility of implementing and enforcing the Safe 
Drinking Water Act of 1974, the Pesticide Control Act, and the Clean Water Act of 1977.

Other U.S. Virgin Islands agencies involved in the management of the water resources are the Public Works Department, the Water and Power Authority, the Virgin Islands Planning Office, and the Health Department. Under Title 30, Section 51, of the Virgin Islands Code, the Commissioner of Public Works is designated to supervise and control the construction, repair, maintenance, operation, and administration of the public-water system. The Virgin Islands Water and Power Authority is responsible for the production and distribution of electrical energy and for the production of potable water from seawater desalination systems. Watermanagement planning is within the charter of the U.S. Virgin Islands Planning Office, but the DCCA is active in planning as well. The Department of Health analyzes the bacteriological and chemical content of private cisterns and wells.

The EPA has not delegated to the U.S.Virgin Islands government the management and implementation of several laws concerning ground-water quality. The EPA is responsible for enforcing the RCRA, which regulates the management of solid and liquid hazardous wastes. There is at present only one RCRA site in the Virgin Islands on St. Croix (fig. 3). Presently, little has been done in water programs in the Virgin Islands regarding toxics identification under the Toxic Materials Act. There are no known problems with respect to industrial discharges to public sewage-treatment plants, and there are very few sources that would be expected to pose problems with respect to toxic-substances discharge (U.S. Environmental Protection Agency, 1979, p. 59).

The continued use of ground water as a drinking-water supply in the U.S. Virgin Islands will require a concerted effort to: (1) develop freshwater while minimizing disturbance to the freshwatersaltwater interface, and (2) reduce the potential for sewage infiltration to aquifers from septic tanks and sewage-treatment plant discharges.

\section{SELECTED REFERENCES}

Buros, O.K.. 1976, Wastewater reclamation project. St. Croix, U.S. Virgin Islands: Black, Crow \& Eidness, Inc., EPA-600/2-76-134, 244 p.
Cederstrom, D.J., 1950, Geology and ground-water resources of St. Croix, Virgin Islands: U.S. Geological Survey Water-Supply Paper 1067, 117 p.

Donnelly, T.W., 1960, The geology of St. Thomas and St. John, Virgin Islands: Second Geology Conference, Mayaguez, Puerto Rico. January 4-9, 1959, Transactions, p. 153-155.

Durfor, C.N., and Becker, Edith, 1964, Chemical quality of public water supplies of the United States and Puerto Rico, 1962: U.S. Geological Survey Hydrologic Investigations Atlas HA-200, 1 sheet.

Garcia, Rene, and Canoy, M.J., 1985, Reconnaissance of ground-water quality in the Virgin Islands, July 1984: U.S. Geological Survey Open-File Report 84-807, 1 plate.

Geraghty and Miller, Inc., 1983, Report on current ground-water conditions in the U.S. Virgin Islands: Syosset, New York, Geraghty and Miller, Inc., 80 p.

Gomez-Gomez, Fernando and Heisel, T.E., 1980, Summary appraisals of the Nation's ground-water resources-Caribbean Region: U.S. Geological Survey Professional Paper 813-U, $32 \mathrm{p}$.

Jordan, D.G., 1975, A survey of the water resources of St. Croix, Virgin Islands: U.S. Geological Survey Open-File Report, 51 p.

Jordan, D.G., and Cosner, O.J., 1973, A survey of the water resources of St. Thomas, Virgin Islands: U.S. Geological Survey Open-File Report, 55 p.

Peebles, R.W. Pratt, A.E., and Smith, H.H., 1979, Waterplan-A comprehensive water management framework for the U.S. Virgin Islands Water Research Center: Caribbean Research Institute, College of the Virgin Islands, $43 \mathrm{p}$.

Robison, T.M. 1972, Ground water in central St. Croix, U.S. Virgin Islands: U.S Geological Survey Open-File Report 72-319, $46 \mathrm{p}$

Robison, T.M., and others, 1973, Water records of the U.S. Virgin Islands 1962-69. U.S. Geological Survey, 163 p.

Torres-Sierra, Heriberto, 1986, Estimated water-use in St. Croix, U.S. Virgin Islands, 1983-1985: in Proceedings of a symposium held in St. Thomas, U.S. Virgin Islands, July 22-25, 1986, p. 7-11

Torres-Sierra. Heriberto, and Dacosta. Rafael, 1984, Water use in St. Thomas, U.S Virgin Islands, July 1983-June 1984; U.S. Geological Survey Open-File Report 84-721, 1 plate.

U.S. Environmental Protection Agency, 1979, Virgin Islands/Environmental Protec tion Agency agreement for water and air related programs: U.S. Environmental Protection Agency, $85 \mathrm{p}$.

1986a, Maximum contaminant levels (subpart 8 of Part 141, National interim primary drinking-water regulations): U.S. Code of Federal Regulations, Title 40, Parts 100 to 149 , revised as of July 1,1986, p. 524-528.

1986b, Secondary maximum contaminant levels (section 143.3 of part 143, National secondary drinking-water regulations): U.S. Code of Federal Regulations, Title 40, Parts 100 to 149, revised as of July 1, 1986, p. 587-590. 1986c. Amendment to National Oil and Hazardous Substances Contingency Plan; national priorities list, final rule and proposed rule: Federal Register, v. 51, no. 111, June 10, 1986, p. 21053-21112.

U.S. Geological Survey, 1985, National water summary 1984-Hydrologic events. selective water quality trends, and ground-water resources: U.S. Geological Survey Water-Supply Paper 2275, 467 p.

Prepared by Allen Zack, Teresita Rodriguez-Alonso, and Angel Roman-Mas

FOR ADDITIONAL INFORMATION: District Chief, U.S. Geological Survey, GPO Box 4424, San Juan, Puerto Rico 00936 

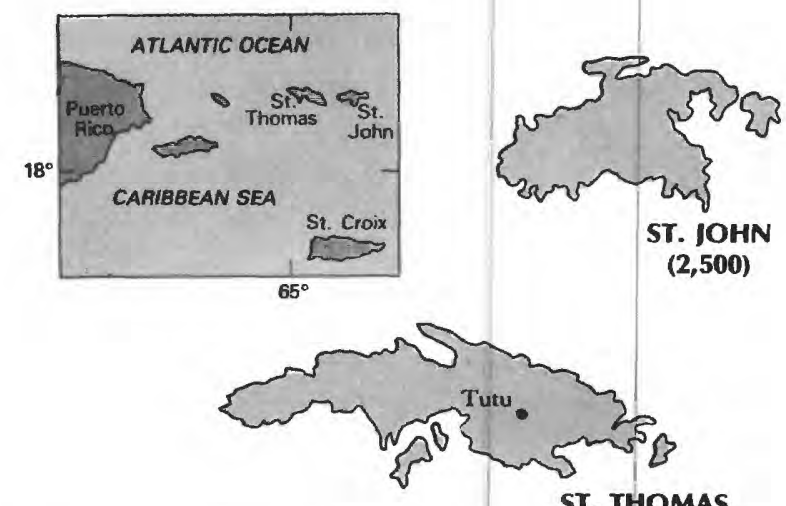

ST. THOMAS

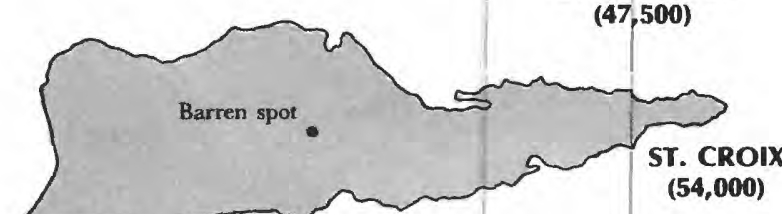

Figure 1. Selected geographic features and 1985 population distribution in the U.S. Virgin Islands. Selected cities and population distribution, 1985; number in parentheses is total by island.(Source: Virgin Islands Office of Policy Planning Research, 1987.) 


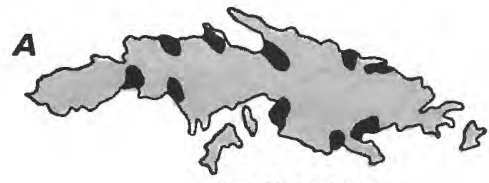

ST. THOMAS

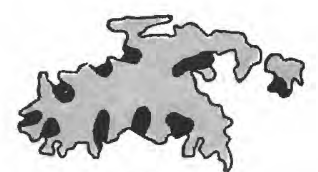

ST. JOHN
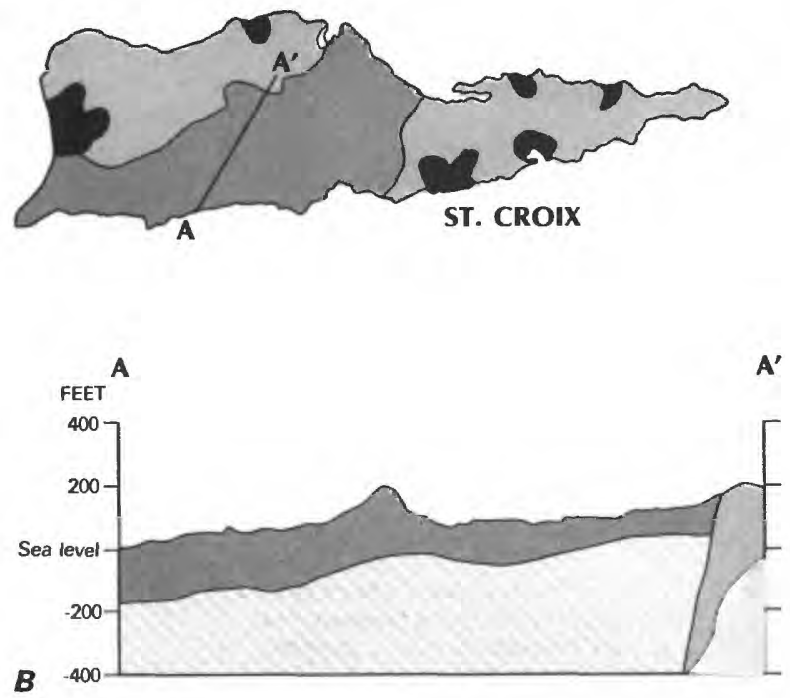
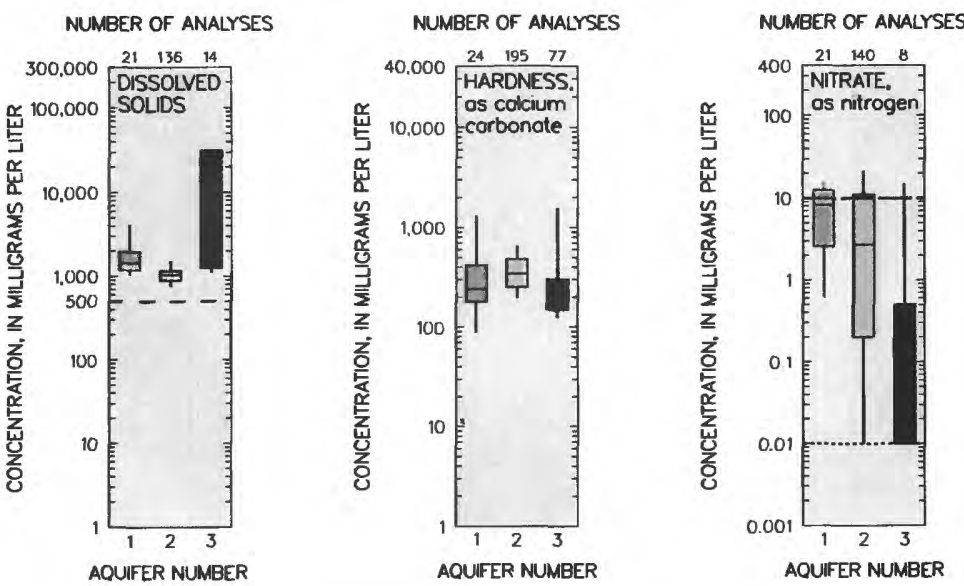

Figure 2. Principal aquiters and related water-quality data in U.S. Virgin Islands. A, Principal aquifers. B, Generalized hydrogeologic section. $C$, Selected water-quality constituents and properties, 1965 to 1985. (Sources: A, Modified from Donnelly, 1960; Cederstrom, 1950. B. Robison, 1972. C, Analyses compiled from U.S. Geological Survey files; national drinking-water standards from U.S. Environmental Protection Agency, 1986a,b.) 

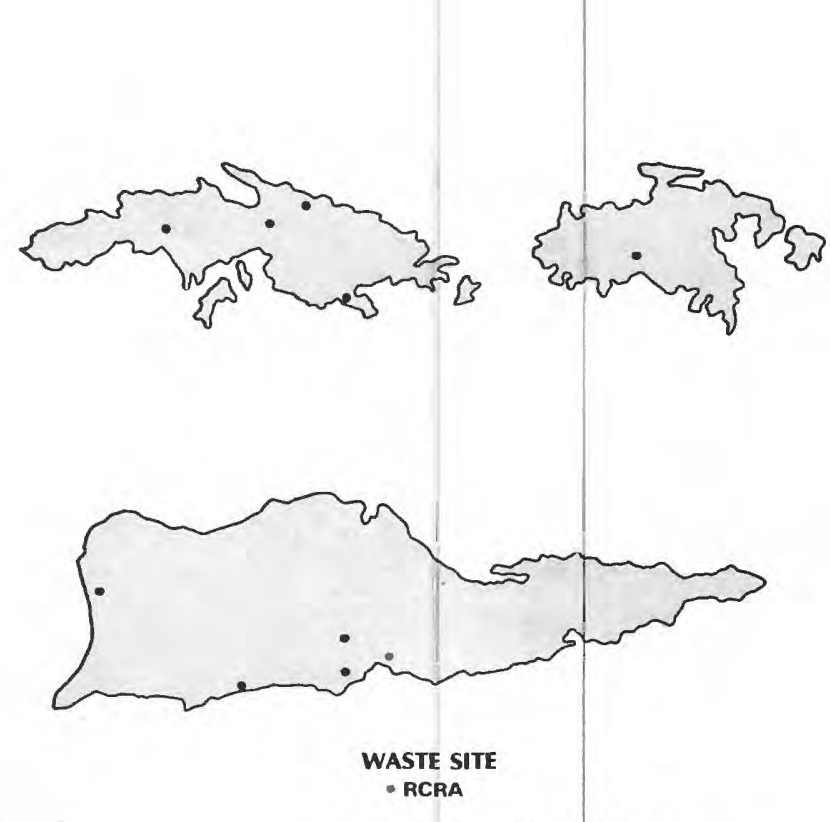

\section{GROUND-WATER QUALITY}

- Well that yialds contaminated water

LANDFILL SITE

- Municipal - Active or inactive

Figure 3. Selected waste sites and ground-water-quality information

in the U.S. Virgin Islands. Resource Conservation and Recovery Act (RCRA) sites as of 1986; distribution of wells that yield contaminated water, as of 1986; municipal landfills, as of 1986. (Sources: Waste sites, L.J. Livingston, U.S. Environmental Protection Agency, written commun., 1986. Ground-water quality sites, Fernando Gomez-Gomez, U.S. Geological Survey, written commun., 1986. Landfill sites, Fernando Gomez-Gomez, 1980.) 